\title{
Mortality of silver eel (Anguilla anguilla) migrating downstream through a small hydroelectric plant on the Drawa River in northern Poland
}

\author{
Piotr Dębowski, Rafał Bernaś, Michał Skóra, Jacek Morzuch
}

Received - 25 January 2016/Accepted - 11 April 2015. Published online: 30 June 2016; $\odot$ Inland Fisheries Institute in Olsztyn, Poland Citation: Dębowski P., Bernaś R., Skóra M., Morzuch J. 2016 - Mortality of silver eel (Anguilla anguilla) migrating downstream through a small hydroelectric plant on the Drawa River in northern Poland - Arch. Pol. Fish. 24: 69-75.

\begin{abstract}
The European eel, Anguilla anguilla L., is an endangered species. Barriers to its downstream spawning migration are one of the greatest threats this species faces. There are hundreds of hydroelectric plants (HEP) on rivers in Poland (> 600), and thousands throughout Europe. Eel that pass through HEP turbines as they migrate downstream suffer high mortality, but this depends mainly on local and technical conditions. Silver eel mortality was estimated and the possibility of the fish bypassing the turbines was studied between November 2013 and June 2014 at a typical HEP in northern Poland. Two telemetry methods were used with 49 eel: passive integrated transponder (PIT) system and acoustic telemetry. Fifty five percent of eel migrated downstream in fall 2013, soon after their release, and 45\% migrated the next spring. The eel did not use the fish passes designed for upstream migration; thus, they were forced to go through the turbines, which resulted in 55\% mortality. HEPs cause interruptions and delays in eel spawning migrations and are responsible for high eel mortality. This can make implementing an eel restitution plan difficult or even impossible in river systems with many barriers.
\end{abstract}

Keywords: eel, hydroelectric plant, mortality, spawning migration

\footnotetext{
P. Dębowski [ [”], R. Bernaś, M. Skóra, J. Morzuch

Department of Migratory Fishes in Rutki

Inland Fisheries Institute in Olsztyn, Poland

e-mail: p.debowski@infish.com.pl
}

\section{Introduction}

The European eel, Anguilla anguilla L., population has decreased dramatically in recent decades, and in the late 1990s, glass eel recruitment was less than $10 \%$ of that in the 1980s (Dekker 2003). This led to the development and implementation of the Eel Regulation by the European Union (Council Regulation (EC) No 1100/2007) that requires all member states to develop national eel management plans. The main requirement of these plans is to ensure escapement to the sea of at least $40 \%$ of the silver eel biomass relative to the estimate of reference amounts with no anthropogenic influences.

The presence of barriers in the downstream migration of adult eel is regarded as one of the main problems in implementing this plan. HEPs have an especially negative influence on migration, as they can delay or even entirely block it. In many HEPs, there is only one route downstream, which is blocked by turbines. Turbines cause injuries, and because of their shape eel are especially endangered (Larinier and Travade 2002). Eel mortality caused by turbines depends on many factors like the type of turbine, its size, rotation speed, and water flow (Čada 2001, McCleave 2001, Larinier and Travade 2002, Winter et al. 2006, Vowles et al. 2014). Turbines can cause

(c) Copyright by Stanisław Sakowicz Inland Fisheries Institute in Olsztyn.

(C) 2016 Author(s). This is an open access article licensed under the Creative Commons Attribution-NonCommercial-NoDerivs License (http://creativecommons.org/licenses/by-nc-nd/3.0/). 
100\% mortality (Monten 1985, Carr and Whoriskey 2008), but this number is usually lower (Monten 1985, Jansen et al. 2007, Winter et al. 2007, Larinier 2008, Calles et al. 2010, Leonardsson 2012).

Lakes are the main environment for freshwater eel production in Poland. There are approximately $2600 \mathrm{~km}^{2}$ of lakes; however, eel can migrate freely from only $630 \mathrm{~km}^{2}(24 \%)$ (Dębowski and Bernaś 2010). One large lake complex in northwest Poland is drained by the Drawa River, the lower segment of which is dammed by a typical HEP. The HEP is equipped with a fish pass designed for the upstream migration of salmonid fish. The aim of this study was to discover if migrating silver eel used the fish pass and to assess the mortality rate of eel passing through the turbines.

\section{Study area}

The Drawa River drains into the Noteć River, a tributary of the Warta River which drains into the Pomeranian Bay (southern Baltic Sea) via the Oder River. The Drawa River is $192 \mathrm{~km}$ long and its catchment area is $3291 \mathrm{~km}^{2}$. There are around $105 \mathrm{~km}^{2}$ of lakes in the area, of which $68 \%$ are upstream from at least one

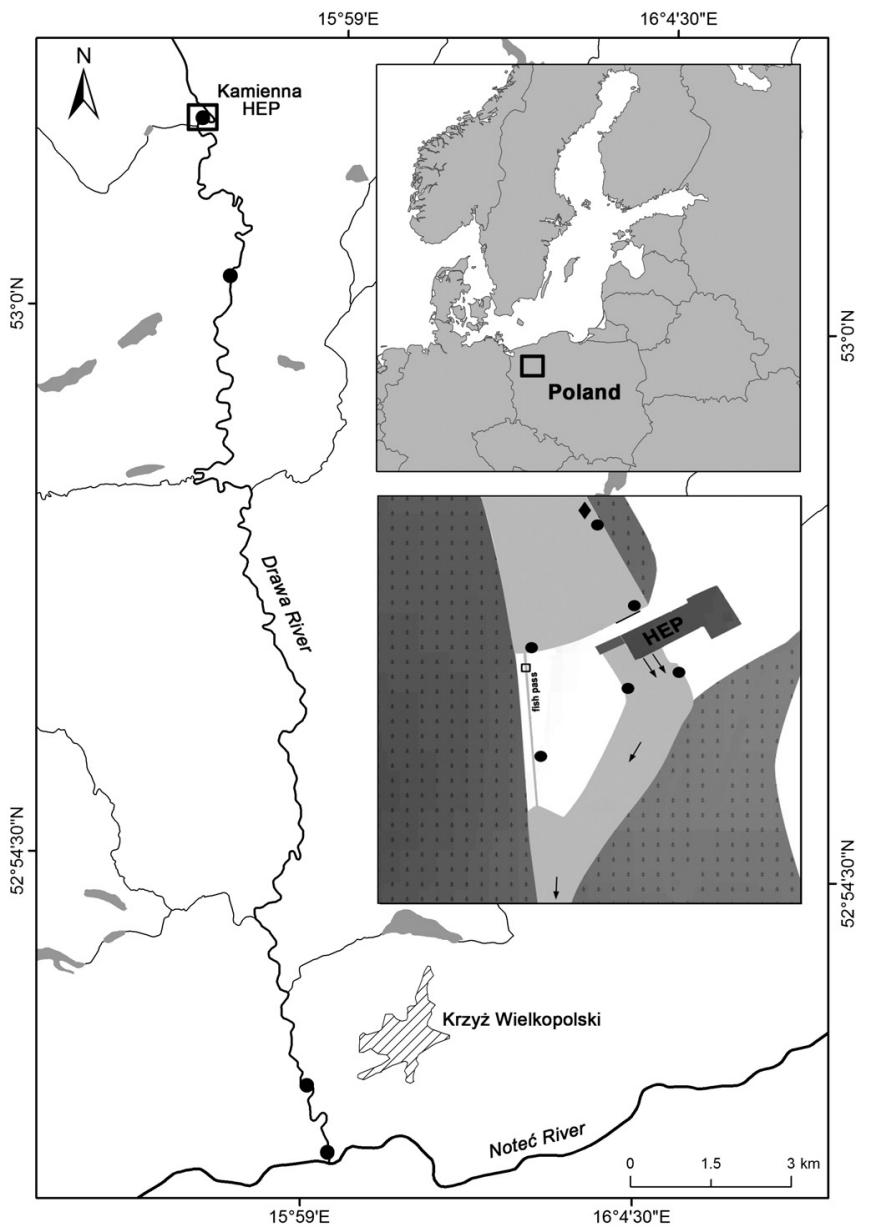

Figure 1. Map showing the location of the Drawa River catchment area (upper right), the Kamienna hydroelectric plant (HEP) in a lower course of the river, and the studied dam (lower right); the release point of the eel is denoted by a black rhombus, acoustic automatic receivers by black dots, and PIT antennae by a rectangle.
HEP. The Drawa River is dammed by four HEPs at 32, 89, 127, and $156 \mathrm{~km}$ from the mouth, and there are no other barriers between the mouth and the sea.

The dam on the Drawa River in the village of Głusko was constructed in 1903, and three years later a HEP was installed. The HEP has not experienced many breakdowns in its history. Water is dammed to $7.4 \mathrm{~m}$ and flows through two Francis turbines at 100 revolutions $\min ^{-1}$ (Borkowska 1990). The power of the HEP is $960 \mathrm{~kW}$, and the installed turbine flow is 21.4 $\mathrm{m}^{3} \mathrm{~s}^{-1}$. The average flow of the river from 1961 to 1999 according to the Institute of Meteorology and Water Management was $12.0 \mathrm{~m}^{3} \mathrm{~s}^{-1}$ (Dębowski and Gancarczyk 2013).
The upper inlet into the fish pass is located at the right end of the dam around $50 \mathrm{~m}$ away from the HEP inlet (Fig. 1). It has two windows measuring $0.40 \mathrm{x}$ $0.45 \mathrm{~m}$ each, one is at the bottom and one is at a surface. The fish pass is a typical concrete construction that is $83.4 \mathrm{~m}$ long with 19 chambers connected by two windows and a nominal flow of $0.430 \mathrm{~m}^{3}$.

\section{Material and methods}

We used two telemetric methods to track the fish-acoustic telemetry to assess the mortality of fish passing through the turbines, and PIT (passive 
integrated transponder) tags (Prentice et al. 1990) to determine if the eel used the fish pass. We used 49 silver eel with total lengths $(L)$ between 70.5 and 100 $\mathrm{cm}\left(L_{a v}=84.8, \mathrm{SD}=6.1\right)$ that had been caught in traps in the mouth of the Oder River. Judging from their size, they were females (Tesch 2003). Their maturity was estimated by the eye index $(I)$ (Pankhurst 1982): $\mathrm{I}=100 \times(((0.25 \times(A+B)) \times 2 \pi) \times \mathrm{L}-1)$; where $\mathrm{A}$ is the vertical eye diameter and $B$ is the horizontal eye diameter. I was from 3.7 to $14.4\left(I_{a v}=8.8\right.$, $\mathrm{SD}=2.9)$.

All eel were tagged with PITs (OregonRFID 3.2 mm HDX), and 24 were fitted with acoustic transmitters (V9-2x, VEMCO, AMIRIX Systems Inc., Halifax, Nova Scotia, Canada). Both were surgically implanted into the body cavity of the fish (Baras and Jeandrain 1998). They were released November 7 , 2013 into the main current of the reservoir $200 \mathrm{~m}$ upstream from the HEP inlet (Fig. 1).The PITs were detected by two loop antennae mounted in the upper part of the fish pass on the two windows between the second and third chambers (Fig. 1). Signals from the acoustic transmitters were detected by nine automatic receivers (VR2W, VEMCO, AMIRIX Systems Inc., Halifax, Nova Scotia, Canada): three in the reservoir above the HEP; one in the fish pass; two directly below the HEP outlet; three in the lower river segment (1.6, 7.2 and $31.9 \mathrm{~km}$ below the dam) (Fig. 1). The receivers were deployed until July, which was longer than predicted life span of the acoustic transmitters. The progression rates of the migrating of eel were calculated using the distances between receivers and the time between the last recorded signal in an upstream receiver and the first signal in a downstream receiver. All statistical analyses were done with STATISTICA 7.1. (StatSoft).

\section{Results}

Neither PITs nor acoustic tags were registered in the fish pass, which indicated that the eel did not use the fish pass. Almost all the fish with acoustic transmitters were recorded swimming in the reservoir after their release, visiting locations near the dam, and returning to the release location. Some fish did this more than once. Four fish did not swim downstream, but disappeared from the reservoir before winter (between November 22 and December 22). Twenty swam through the turbines. The first eel did so only three hours after release and the last did so seven months following release (Fig. 2). They began their downstream migration during the day and evening and avoided late night and morning hours (Fig. 3). Eleven fish swam downstream in fall-winter: seven in the first week and four in January, with the last leaving when the temperature was below $5^{\circ} \mathrm{C}$. Nine eel emigrated in the spring: the first at the end of March after the temperature increased to $8^{\circ} \mathrm{C}$, the rest, one by one, up to the beginning of June when the water temperature was $16^{\circ} \mathrm{C}$ (Fig. 2). River discharge during the study was stable, so no relation with this factor was noted (Fig. 2). The average lengths (85.6 vs $84.7 \mathrm{~cm}$, t-test, $\mathrm{P}=0.6782$ ), or eye indices (10.2 vs 10.4 , t-test, $\mathrm{P}=0.8492)$ of the fall and spring migrants did not differ upon release.

Nine fish, six in fall and three in spring, reached the Drawa River mouth, $32 \mathrm{~km}$ below the dam (the

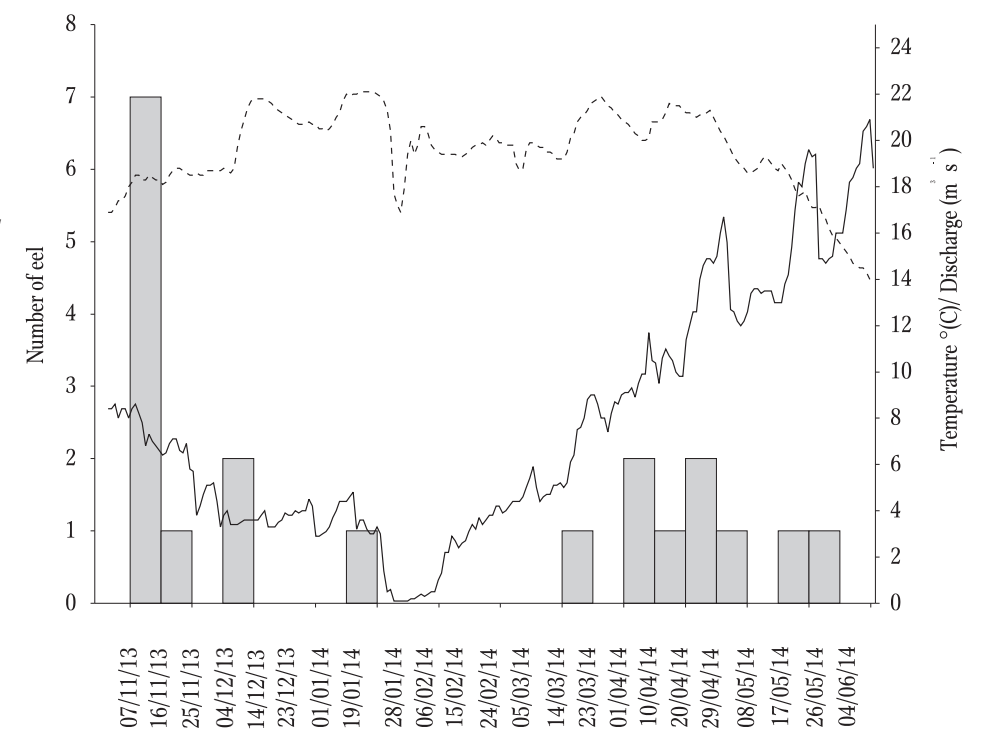

Figure 2. Number of eel (A. anguilla) passing through turbines $(\mathrm{N})$, water temperature $\left(\mathrm{T},{ }^{\circ} \mathrm{C}\right.$, solid line) and discharge in lower Drawa River $\left(\mathrm{Q}, \mathrm{m}^{3} \mathrm{~s}^{-1}\right.$, broken line). 
Table 1

Fate of eel (A. anguilla) with acoustic transmitters (numbers)

\begin{tabular}{lllll}
\hline & Survivors-Uninjured & Injured & Dead & Total \\
\hline \hline Non-migrants & - & - & - & 4 \\
Spring migrants & 3 & 4 & 2 & 9 \\
Fall migrants & 6 & 1 & 4 & 11 \\
Total & 9 & 5 & 6 & 24 \\
\hline \hline
\end{tabular}

3.
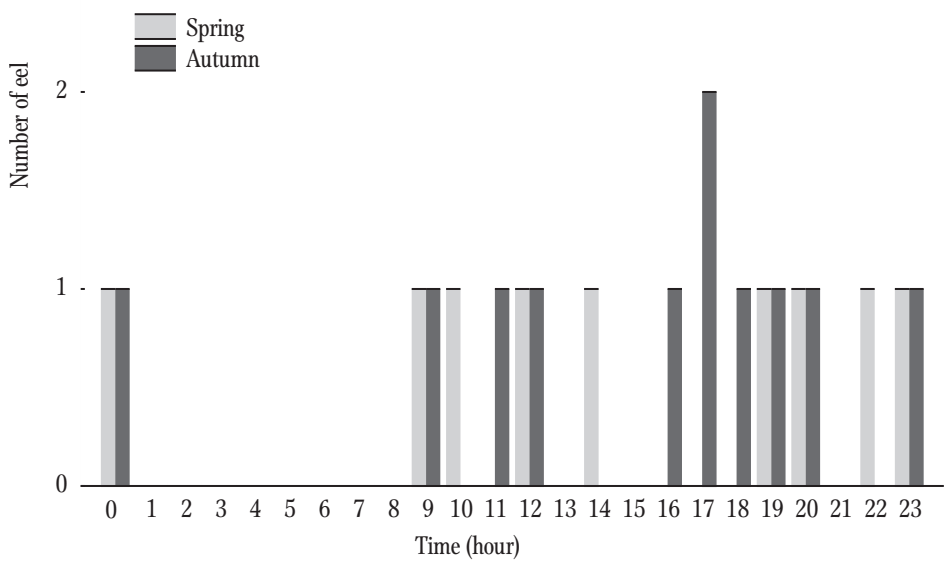

Figure 3. Number of migrating eel (A. anguilla) in relation to time of day in fall and spring.

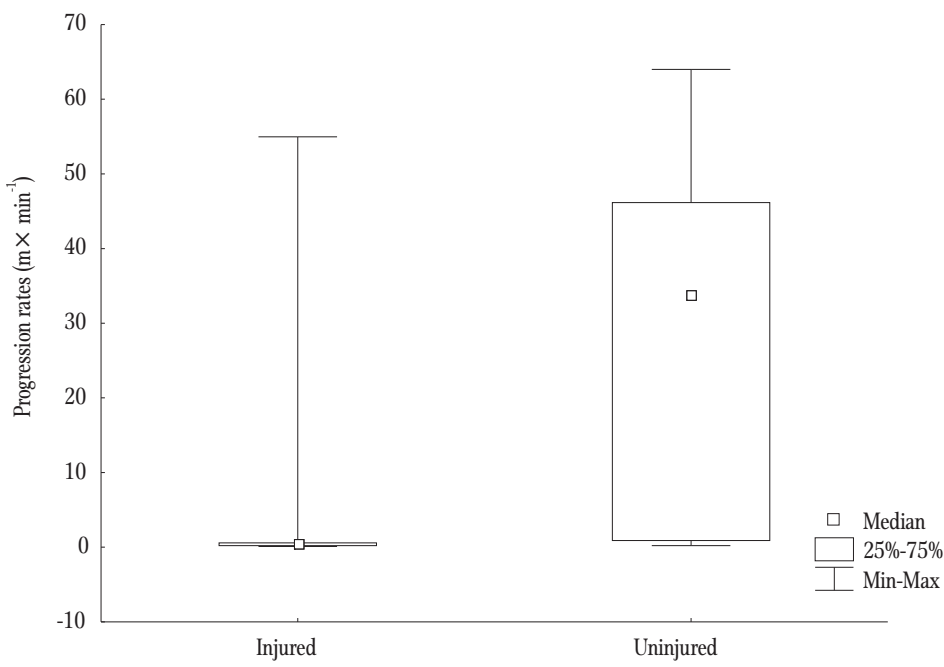

Figure 4. Progression rates $\left(\mathrm{S}, \mathrm{m} \mathrm{min} \mathrm{m}^{-1}\right)$ of injured and uninjured eel $(A$. anguilla) below the dam. first group). Five fish, one in fall and four in spring, were registered 1.6 and/or $7.2 \mathrm{~km}$ below the dam, but did not reach the mouth (the second group). Six fish, four in fall and two in spring, were only registered directly below the outflow from the turbine (the third group). Eel from the third group were considered deceased, and eel from the first group were considered uninjured (Table 1). Fish from the second group were assumed to be injured and unable to migrate further. This assumption was supported by their lower progression rate below the dam in comparison with eel from the first group (Fig. 4) (insignificant difference: t-test, $P=0.2316$ ). The total mortality (dead plus injured) of eel passing through the turbines was estimated at $55 \%$.

There were no significant differences between the average lengths of the survivors and those that died (including injured): 84 vs $96 \mathrm{~cm}$ (t-test, $\mathrm{P}=0.3783$ ). The average progression rates of eel between the dam and the mouth ranged from 1 to $66 \mathrm{~m} \times \mathrm{min}^{-1}$, with the fastest fish covering the distance in eight hours.

\section{Discussion}

Mature eel migrate throughout the year (Reckordt et al. 2014) with concentrated migration peaks occurring in spring and fall (Tesch 2003, Acou et al. 2008, Reckordt et al. 2014, Stein et al. 2014, 2015). Silvering 
is usually completed from September to November (van Ginneken et al. 2007), and migration is triggered by environmental cues. It is obviously regulated by water temperature (Verbiest et al. 2012, Reckordt et al. 2014, Stein et al. 2014, 2015); however, this relationship is not clear and can change depending on the location and the time of year (Durif et al. 2002, Tesch 2003, Carr and Whoriskey 2008). Eel usually do not migrate when the water temperature is below 4 and above $18^{\circ} \mathrm{C}$ (Vøllestad et al. 1986, Tesch 2003), and prefer the range of $10-14^{\circ} \mathrm{C}$ (Durif et al. 2002), but Reckordt et al. (2014) also observed migration below $5^{\circ} \mathrm{C}$. The behavior of the eel in our experiment generally reflected these observations. Many authors emphasized that increased water levels trigger downstream eel migration (Durif et al. 2002, Behrmann-Godel and Eckmann 2003, Jansen et al. 2007, Acou et al. 2008, Travade et al. 2010, Verbiest et al. 2012, Stein et al. 2014, Barry et al. 2016). The flow of the Drawa River is very stable (Stachy et al. 1986), which mitigates this factor. Eel often interrupt migration after water temperature decreases in late fall and resume it in spring, when water temperatures increase (Acou et al. 2008, Stein et al. 2014, 2015). Half of the fish in our experiment exhibited this behavior.

Silver eel usually stop migrating when confronted with a barrier often swimming back and along dams, or they search for a path downstream (Haro et al. 2000, Behrmann-Godel and Eckmann 2003, Winter et al. 2006, Brown et al. 2007, Jansen et al. 2007, Acou et al. 2008, Travade et al. 2010, Pedersen et al. 2011, Piper et al. 2013, Calles et al. 2013, Stein et al. 2015). The eel in our experiment behaved similarly. The fish approached the vicinity of the fish pass, but the eel did not use the pass. Evidently, they were not attracted to this small outlet. Eels migrate in the main water current, and if they bypass turbines, they utilize high water to swim through spillways (Durif et al. 2002, Boubee and Williams 2006, Acou et al. 2008, Calles et al. 2010). Eel use fish passes designed for upstream migration sporadically (Jansen et al. 2007, Carr and Whoriskey 2008, Travade et al. 2010, Verbiest et al. 2012).

Eel usually migrate at night (Haro et al. 2000, Durif et al. 2002, Tesch 2003, Carr and Whoriskey 2008, Travade et al. 2010), and they only migrate during the day in turbid water (Durif et al. 2002, Travade et al. 2010). The fish in the present experiment did not avoid migrating during the day. Perhaps the light conditions in late fall and early spring were suitable. Regardless, they also preferred migrating during the early evening.

The character and severity of injuries sustained when eel passed through the turbines depended on many factors connected to the characteristics of both the turbines and eel, including size and behavior (Monten 1985, McCleave 2001, Leonardsson 2012). Some of the consequences of injury were immediate, while others appeared only after a period of time (Monten 1985, Richkus and Dixon 2003). Delayed consequences were not easy to assess with telemetric methods. Nevertheless, it appeared that the eel that swam actively for a distance of $32 \mathrm{~km}$ immediately after passing through the turbines could not have been injured.

Total mortality was estimated at $55 \%$, which was high for a Francis turbine. In the majority of experiments carried out on this type of turbine, the mortality of eel was below 20\% (McCleave 2001, Richkus and Dixon 2003). However, in some rates reached $60 \%$ (Calles et al. 2010) or even 100\% (Monten 1985). Leonardsson (2012) estimated the average for 191 hydropower stations in southern Sweden to be 30\%, and if omitting the largest rivers the predicted losses to 60-70\%. The high mortality in our experiment could have stemmed from the large size of the eel.

Subject HEPs, and their characteristics are typical of Pomerania. Therefore, it can be assumed that the mortality of silver eel passing through other HEPs is similar. There are many HEPs on many rivers, and passing through three similar HEPs could result in 90\% mortality for silver eel. This can make implementing an eel restitution plan difficult or even impossible in river systems with many barriers. 
Acknowledgments. This study was funded by the European Commission Operational Programme 00002-61721-194 OR1400003/10/11 and statutory topic S-25 at the Inland Fisheries Institute in Olsztyn.

Author contributions. P.D. designed the research; P.D., R.B., M.S., and J.M. performed the research; P.D. analyzed the data; P.D. and R.B. wrote the paper.

\section{References}

Acou A., Laffaille P., Legault A., Feunteun E. 2008 - Migration pattern of silver eel (Anguilla anguilla, L.) in an obstructed river system - Ecol. Freshw. Fish 17: 432-442.

Baras E., Jeandrain D. 1998 - Evaluation of surgery procedures for tagging eel Anguilla anguilla (L.) with biotelemetry transmitters - Hydrobiologia 371/372: 107-111.

Barry J., Newton M., Dodd J.A., Lucas M.C., Boylan P., Adams C.E. 2016 - Freshwater and coastal migration patterns in the silver-stage eel Anguilla anguilla - J. Fish Biol. 88: 676-689.

Behrmann-Godel J., Eckmann R. 2003 - A preliminary telemetry study of the migration of silver European eel (Anguilla anguilla L.) in the River Mosel, Germany - Ecol. Freshw. Fish 12: 196-202.

Borkowska M. 1990 - Kamienna-Głusko hydroelectric plant on the Drawa River. Historical-architectural specifications - P.P. Pracownie Konserwacji Zabytków, Pracownia Dokumentacji Naukowo-Historycznej, Szczecin (in Polish).

Boubee J., Williams E.K. 2006 - Downstream passage of silver eels at a small hydroelectric facility - Fisheries Manag. Ecol. 13: 165-176.

Brown L.S., Boubee J., Haro A. 2007 - Behaviour and fate of downstream migrating eels at hydroelectric power station intakes - 6th International Symposium on Ecohydraulics, Christchurch, NZ. 1-5.

Čada G.F. 2001 - The development of advanced hydroelectric turbines to improve fish passage survival - Fisheries 26: 14-23.

Calles O., Olsson I.C., Comoglio C., Kemp P.S., Blunden L., Schmitz M., Greenberg L.A. 2010 - Size-dependent mortality of migratory silver eels at a hydropower plant, and implications for escapement to the sea-Freshw. Biol. 55: 2167-2180.

Calles O., Karlsson S., Vezza P., Comoglio C., Tielman J. 2013 - Success of a low-sloping rack for improving downstream passage of silver eels at a hydroelectric plant - Freshw. Biol. 58: 2168-2179.
Carr J.W., Whoriskey F.G. 2008 - Migration of silver American eels past a hydroelectric dam and through a coastal zone - Fisheries Manag. Ecol. 15: 393-400.

Dekker W. 2003 - Did lack of spawners cause the collapse of the European eel, Anguilla anguilla? - Fisheries Manag. Ecol. 10: 365-376.

Dębowski P., Bernaś R. 2010 - Possibility of silver eel migration in Poland - Komun. Ryb. 2: 25-27 (in Polish).

Dębowski P., Gancarczyk J. 2013 - Effectiveness of the fish pass at the Kamienna hydroelectric plant on the Drawa River - Komun. Ryb. 4: 1-7 (in Polish).

Durif C., Elie P., Gosset C., Rives J., Travade F. 2002 - Behavioral study of downstream migrating eels by radio-telemetry at a small hydroelectric power plant - In: Biology, management, and protection of catadromous Eels (Ed) D.A. Dixon, American Fisheries Society Symposium 33, Bethesda, Maryland: 343-356.

Haro A., Castro-Santos T., Boubée J. 2000 - Behavior and passage of silver phase American eels at a small hydroelectric facility - Dana 12: 33-42.

Jansen H.M., Winter H.V., Bruijs M.C.M., Polman H.J.G. 2007 - Just go with the flow? Route selection and mortality during downstream migration of silver eels in relation to river discharge - ICES J. Mar. Sci. 64: 1437-1443.

Larinier M. 2008 - Fish passage experience at small-scale hydro-electric power plants in France - Hydrobiologia 609: 97-108.

Larinier M., Travade F. 2002 - Downstream migration: problems and facilities - Bull. Fr. Pechę Piscic. 364 Suppl.: 181-207.

Leonardsson K. 2012 - Modellverktyg för beräkning av allförluster vid vattenkraftverk - Elforsk rapport 12:36. Elforsk - AB, Stockholm.

McCleave J.D. 2001 - Simulation of the impact of dams and fishing weirs on reproductive potential of Silver-Phase American Eels in the Kennebec River Basin, Maine - N. Am. J. Fish. Manage. 21: 592-605.

Monten E. 1985 - Fish and turbines. Fish injury during passage through power station turbines - Vattenfall, Stockholm.

Pankhurst N.W. 1982 - Relation of visual changes to the onset of sexual maturation in the European eel Anguilla anguilla (L.) - J. Fish Biol. 21: 127-140.

Pedersen M.I., Jepsen N., Aarestrup K., Koed A., Pedersen S., Okland F. 2011 - Loss of European silver eel passing a hydropower station - J. Appl. Ichthyol. 27: 1-5.

Piper A.T., Wright R.M., Walker A.M., Kemp P.S. 2013 Escapement, route choice, barrier passage and entrainment of seaward migrating European eel, Anguilla anguilla, within a highly regulated lowland river - Ecol. Eng. 57: 88-96.

Prentice E.F., Flagg T.A., McCutcheon C.A., Brastow D.F. 1990 - PIT-tag monitoring systems for hydroelectric 
dams and fish hatcheries - American Fisheries Society Symposium 7: 323-334.

Reckordt M., Ubl C., Wagner C., Frankowski J., Dorow M. 2014 - Downstream migration dynamics of female and male silver eels (Anguilla anguilla L.) in the regulated German lowland Warnow River - Ecol. Freshw. Fish 23: 7-20.

Richkus W.A., Dixon D.A. 2003 - Review of research and technologies of passage and protection of downstream migrating catadromous eels at hydroelectric facilities American Fisheries Society Symposium 33: 377-288.

Stein F., Calles O., Hubner F., Ostergren J., Schroder, B. 2014 - Understanding downstream migration timing of European eel (Anguilla anguilla ) - Analysis and modelling of environmental triggers - Elforsk - AB, Stockholm, Elforsk rapport 14: 51 .

Stein F., Doering-Arjes P., Fladung E., Brämick U., Bendall B., Schröder B. 2015 - Downstream migration of the European eel (Anguilla anguilla) in the Elbe River, Germany: movement patterns and the potential impact of environmental factors - River Res. Appl. 32:666-667.

Stachy J., Fal B., Orsztynowicz J. 1986 - River runoff - In: Hydrological atlas of Poland (Ed.) J. Stachy, Instytut Meteorologii i Gospodarki Wodnej, Wydawnictwo Geologiczne Warszawa: 229-518 (in Polish).

Tesch F.W. 2003 - The eel - Blackwell, London, 397 p.

Travade F., Larinier M., Subra S., Gomes P., De-Oliveira E. 2010 - Behaviour and passage of European silver eels (Anguilla anguilla) at a small hydropower plant during their downstream migration - Knowl. Managt. Aquatic Ecosyst. 398: 1-19.

Van Ginneken V., Durif C., Balm S.P., Boot R., Verstegen M.W.A., Antonissen E., Van Den Thillart G. 2007 Silvering of European eel (Anguilla anguilla L.): seasonal changes of morphological and metabolic parameters Anim. Biol. 57: 63-77.

Verbiest H., Breukelaar A., Ovidio M., Philippart J.C., Belpaire C. 2012 - Escapement success and patterns of downstream migration of female silver eel Anguilla anguilla in the River Meuse - Ecol. Freshw. Fish 21: 395-403.

Vøllestad L.A., Jonsson B., Hvidsten N.A., Naesje T.F., Haraldstad O., Ruud-Hansen J. 1986 - Environmental factors regulating the seaward migration of European silver eels Anguilla anguilla - Can. J. Fish. Aquat. Sci. 43: 1909-1916.

Vowles A.S., Karlsson S.P., Uzunova E.P., Kemp P.S. 2014 The importance of behaviour in predicting the impact of a novel small-scale hydropower device on the survival of downstream moving fish - Ecol. Eng. 69: 151-159.

Winter H.V., Jansen H.M., Breukelaar A.W. 2007 - Silver eel mortality during downstream migration in the River Meuse, from a population perspective - ICES J. Mar. Sci. 64: 1444-1449.

Winter H.V., Jansen H.M., Bruijs M.C.M. 2006 - Assessing the impact of hydropower and fisheries on downstream migrating silver eel, Anguilla anguilla, by telemetry in the River Meuse - Ecol. Freshw. Fish 15: 221-228. 